\title{
New Zealand Building Project Cost and Its Influential Factors: A Structural Equation Modelling Approach
}

\author{
Linlin Zhao $\mathbb{D}^{1},{ }^{1}$ Bill Wang $\mathbb{D}^{2},{ }^{2}$ Jasper Mbachu, ${ }^{3}$ and Zhansheng Liu ${ }^{4}{ }^{4}$ \\ ${ }^{1}$ Senior Lecturer, College of Architecture and Civil Engineering, Beijing University of Technology, Beijing 100124, China \\ ${ }^{2}$ Senior Lecturer, Business Information Systems, Auckland University of Technology, Auckland 0632, New Zealand \\ ${ }^{3}$ Associate Professor, Faculty of Society \& Design, Bond University, Gold Coast, QLD 4226, Australia \\ ${ }^{4}$ Associate Professor, College of Architecture and Civil Engineering, Beijing University of Technology, Beijing 100124, China \\ Correspondence should be addressed to Zhansheng Liu; liuzhansheng83@sohu.com
}

Received 21 January 2019; Accepted 16 April 2019; Published 28 May 2019

Academic Editor: Reza Akhavian

Copyright (C) 2019 Linlin Zhao et al. This is an open access article distributed under the Creative Commons Attribution License, which permits unrestricted use, distribution, and reproduction in any medium, provided the original work is properly cited.

\begin{abstract}
Construction industry significantly contributes to New Zealand's economic development. However, the delivery of construction projects is usually plagued by cost overruns, which turn potentially successful projects into money-losing ventures, resulting in various other unexpected negative impacts. The objectives of the study were to identify, classify, and assess the impacts of the factors affecting project cost in New Zealand. The proposed research model was examined with structural equation modelling. Recognising the lack of a systematic approach for assessing the influencing factors associated with project cost, this study identified 30 influencing factors from various sources and quantified their relative impacts. The research data were gathered through a questionnaire survey circulated across New Zealand construction industry. A total of 283 responses were received, with a $37 \%$ response rate. A model was developed for testing the relationship between project cost and the influential factors. The proposed research model was examined with structural equation modelling (SEM). According to the results of the analysis, market and industry conditions factor has the most significant effect on project cost, while regulatory regime is the second-most significant influencing factor, followed by key stakeholders' perspectives. The findings can improve project cost performance through the identification and evaluation of the cost-influencing factors. The results of such analysis enable industry professionals to better understand cost-related risks in the complex environment.
\end{abstract}

\section{Introduction}

The New Zealand construction industry has been experiencing a rapid economy growth due to the increasing demand for projects [1]. Hence, construction industry contributes significantly to the nation's economic development. However, the industry has been plagued by cost overruns in project delivery due to their magnitude and complex nature [2-4]. Cost overruns constitute one of the major reasons of failure in construction projects [5]. Cost performance is essential to the parties involved in a construction project, and it is usually considered as a key factor in determining project success [6]. Therefore, managing cost-related risks is vital to achieve successful outcomes. Risk management includes risk identification, risk classification, risk assessment, and risk control [7-9], all of which should be involved in project management to ensure a successful project outcome. Successful projects can add value for money in terms of timely completion, quality, and aesthetics. The ignorance of the identification of the cost-influencing factors or a lack of knowledge of the project context gives risk to the failure of project. Preventing project failure can be achieved through the analysis of cost-influencing factors. It is necessary to identify all the factors that significantly influence project costs in New Zealand for improving the project cost performance.

Many studies have been conducted to investigate costinfluencing factors and develop a model for effective and systematic assessment of the influencing factors. This topic is not new, and it has been discussed over the last decade [10], 
which indicates different levels of complexity such as the interrelationships between influencing factors and interaction between the influencing factors and project surrounding environment. For example, according to Zoysa and Russell [11], a checklist of risks can be constructed to assist decision makers during the project implementation. The identification and classification of influential factors on the checklist and their possible impact on project costs were assessed primarily through brainstorming, interviews, surveys, and experts' judgements. However, the checklist approach has serious flaws. First, listing the individual influential factors as if they are independent factors ignores the interactions between them. Second, the checklist approach measures the pairwise correlation between influential factors and the project cost without considering the multiple influencing effects.

Few studies that investigate the factors influencing project cost in New Zealand have been performed. The rapid growth of the construction industry requires development of an efficient and effective model that describes the relationship between influencing factors and project cost. This model can be used by developers or clients to conduct cost management, with the goal of improving cost performance. The objectives of the current study are as follows: (1) identify the factors affecting project cost in New Zealand; (2) categorize the factors into groups; and (3) develop a structural model to describe the relationships between project cost and influencing factors. Assessing the effect of the individual influential factors, irrespective of the multiple effects of several influential factors, may result in underestimating the overall effects on the project cost. This paper attempts to mitigate the negligence of previous research and studies that measured separate influential factors (a generic checklist and one-way influencing hierarchies) and proposes a structural model that describes the relationships between the project costs and cost-influencing factors. Hence, this study uses structural equation modelling to incorporate all the influencing factors (latent and observed variables) and project cost into a structural model.

The advantages of structural equation modelling (SEM) are presented as follows: (i) it has fewer sample size and sampling distribution requirements [12], (ii) it can be used to develop the relationship model between a number of indicators and constructs [13], and (iii) it can be used for exploratory studies [14]. In addition, structural equation modelling can help to measure multiple effects of the various influential factors and to emphasize that construction professionals should identify influential paths rather than individual influential factors to better simulate project conditions.

The following sections are organised as follows. Section 2 reviews literature on cost-influencing factors and identifies the gaps that the study tends to fill. Section 3 presents the conceptual framework that describes the variables and hypothetical relationships of the proposed model. Section 4 illustrates the research methodology including empirical data collection and analysis methods. Section 5 describes the data analysis procedures. Section 6 summarises the analysis results, and based on these, discussion is presented.
Conclusion, implementation, and contribution are presented in the final section.

\section{Literature Review}

2.1. Factors Affecting Project Cost. The term "cost" may have different interpretations for different professionals in the construction industry. Its meaning usually lies in the context in which it is being used. For example, cost to the contractor refers to all project expenditures, while cost to the client represents the price that the contractor charged for the work [15]. Project cost indicates different meanings and is usually not compiled in a uniform manner [16]. Project cost in this study includes capital construction cost, associated capital cost, and a client's other costs [17].

In [18], the study explored the 18 primary factors that affect costs in all types of construction projects and validated them via interviews with industry professionals. In this study, cost-influencing factors including project scope and contract document conflicts were categorized into internal group, while the factors such as inflation effects, market conditions, local environment, and unforeseen events were classified into external group. A study conducted by Kaliba et al. [19] explored the cause of cost increases based on a literature review, structural interviews, and a questionnaire survey. This study pointed out that cost-influencing factors include local regulations, weather conditions, technical challenges, and environmental protection.

The study performed by Cha and Shin [20] identified 49 cost-influencing factors and quantified the relative importance of each by normalizing methods to improve project cost performance. In this study, a comprehensive list of costinfluencing factors was provided, which involves construction resource shortage, procurement method, the contractors' skills and experience, building code and regulations, technology issues, tax regulations, interest rate and exchange rate, conflicts, health and safety issues, clients' responsibilities, and site conditions. In [21], the study identified 78 cost-influencing factors based on a literature review, and 48 of them were selected to design a survey that was distributed to clients, consultants, and contractor groups. Their influencing levels were ranked by the participants, and the collected data were analysed using statistical methods. The cost-influencing factors explored by this study include project type, consultants' expertise and experience, market conditions, and price fluctuations.

In [22], the study explored 35 cost-influencing factors and grouped them into seven categories. A survey was conducted to allow industry professionals to rank the influencing level of the factors, and the relative importance index was used to identify the key cost-influencing factors. The key cost-influencing factors included material price fluctuation, cash flow management, financial loan supply and cost, and competence of construction professionals. According to [4], the cost-influencing factors were first identified based on a literature review and then were categorized by using the Kawakita Jiro method, and a survey was conducted to identify the key cost-influencing factors. There are 16 key cost-influencing factors such as natural 
disasters, material shortages and delivery delays, procurement systems, and project participants.

In [23], the study identified the indicators of cost performance that were not be studied in the literature by using a survey, and then, the identified factors were ranked, based on the opinion of industry professionals. This study revealed the cost-influencing factors including legal and political stability and contract conditions. In [24], the study explored 13 key cost-influencing factors based on a literature review and validated them by using a questionnaire. The key costinfluencing factors include economic stability, adequate cash flow, procurement system, and weather conditions.

2.2. Gaps in Existing Literature. A variety of studies about factors affecting cost in the context of construction have been conducted, which comprise studies of project cost associated with project characteristics [25] and costs related to influences from clients, contractors, and others $[26,27]$. Although many studies have been performed regarding the factors that influence project cost, a comprehensive study that includes all the significant influencing factors of project cost in New Zealand has rarely been conducted. Moreover, factors influencing project cost in the construction industry are also viewed as a holistic entity. However, studies performed in the construction industry usually examine the correlation between the influencing factor and project cost rather than investigating the effect that all the influencing factors work collaboratively on the project cost. There is no study incorporating cost-influencing factors into a cohesive model. Therefore, developing a model that incorporates all the cost-influencing factors and project cost to examine their relationships is required.

\section{Conceptual Framework}

The cost-influencing factors have been classified into different groups in previous studies. According to the findings of [4], the identified cost-influencing factors were grouped into four categories: environmental and circumstantial influences, scope of contracts, project risks, and management technique. Based on the finding of [22], the identified costinfluencing factors were categorized into seven groups. In [24], the identified cost-influencing factors were categorized into three groups. Previous studies provide the theoretical foundation for the development of this study's research model. A critical view of the existing literature and brainstorming workshop with experts led to this study separating the cost-influencing factors into five categories. It is assumed that the project characteristics factor, influence of project stakeholders, property market, construction industry, statutory and regulatory factors, and macroeconomic dynamics collectively impact project cost in New Zealand. The project cost factor can be measured by three key indicators: capital construction costs, associated capital costs, and a client's other costs [17].

The project characteristics factor (PCF) is an essential project-related driver of project cost. PCF comprises the attributes associated with site accessibility, project complexity, supply chain, contract selection, and novel technology $[28,29]$. All of these project-related attributes are important for understanding the challenges and complexity associated with the buildability of a project. Thus, it is hypothesised that the PCF has significant effects on project cost in New Zealand.

The key stakeholders' perspectives factor is a measurement of the degree of influence of clients, consultants, contractors, suppliers, and building officers [27, 30]. The key stakeholders' influences factor may affect the quality and performance of a project and thus influence project cost. According to [31], project success is related to all participants' contributions. Increased cost may not only be due to poor performance of the contractors but also inadequate client finances, lack of communication between parties, and the late provision of consultant advice and information. The measurement of the stakeholders' influences should therefore take into account the influences of several participants. Perhaps, the most important of these is the client, who plays a key role in any building project. The client-related factors include finance cash flow, payment for work, and decision-making [32-34]. Moreover, the contractors' work also has significant influence on the building costs, as explained by Park [31, 34]. For example, suitable design may contribute to the success of a project, while defective design work is a major risk for any project. In addition, the ineffective contribution of other project participants is considered to be a major cause of increased costs $[35,36]$. The project participants' expertise and experience have significant impacts on building costs. However, the project participants' attitudes toward the project also significantly affect collaboration and quality of service $[37,38]$. Similarly, improved understanding and trust via communication among involved parties is beneficial [39].

Market and industry conditions can be represented by resource market, competition level, market properties, boom and bust cycle, relationship of supply and demand, investment tendency and confidence, and housing sale/rental prices $[40,41]$. Therefore, it has been hypothesised that the property market and construction industry factor is one of the key criteria that influences project cost in New Zealand. Furthermore, the property market and construction industry factor may impact the project component costs, and thus, both are perceived to be mutually inclusive in the context of factors that influence project cost in New Zealand.

Regulatory regime includes building code and compliance, health and safety regulations, political policy, financial regulations, and the Construction Contract Act [42-44]. Macroeconomic dynamics involve global economic trends, global political stability, natural forces, employment, population, labor cost, economic inflation, and exchange rate [20,45].

Using this framework of factors and dimensions of project cost, a hypothetical diagram of the structural model is presented in Figure 1. The arrow represents the direction of hypothesised influences in the structural model. The corresponding hypotheses are as follows:

(i) Hypothesis 1. The project characteristics factor has a significant effect on project cost in New Zealand

(ii) Hypothesis 2. Key stakeholders' perspectives can significantly influence project cost in New Zealand 


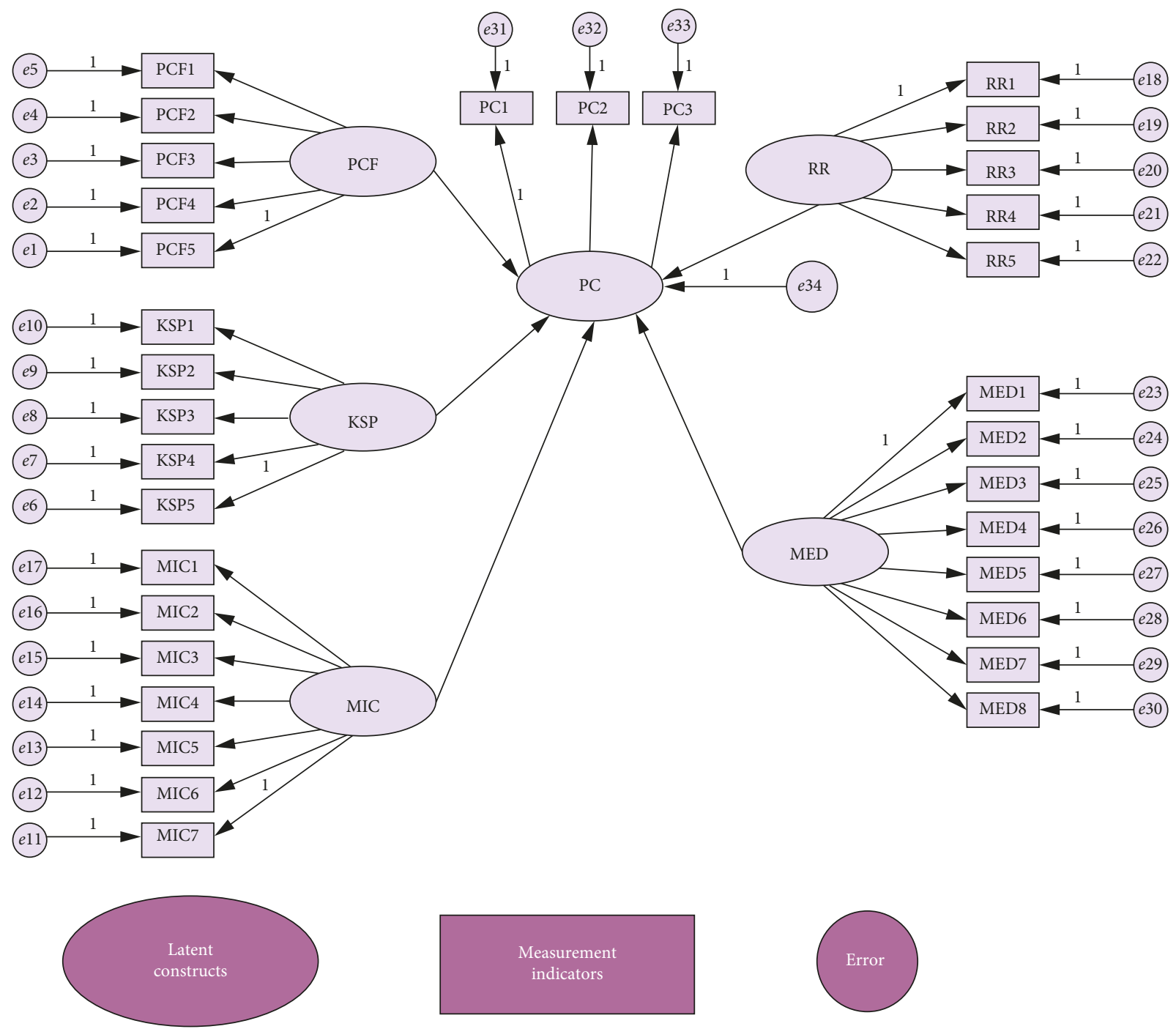

PCF: Project characteristics factor

PCF1: Site accessibility

PCF2: Project complexity

PCF3: Supply chain

PCF4: Contract selection

PCF5: Novel technology

KSP: Key stakeholders' perspectives

KSP1: Clients

KSP2: Consultants

KSP3: Contractors

KSP4: Building officers

KSP5: Suppliers

MIC: Market and industry conditions
MIC1: Resource markets

MIC2: Competition leve

MIC3: Market properties

MIC4: Boom and bust cycle

MIC5: Relationship of supply \& demand

MIC6: Investment tendency \& confidence

MIC7: House sell \& rental prices

RR: Regulatory regime

RR1: Building codes

RR2: Health and safety regulations

RR3: Political policy

RR4: Financial regulations

RR5: Construction contract act
MED: Macro-economic dynamics MED1: Global economic trends MED2: Global political stability MED3: Natural forces

MED4: Employment

MED5: Population

MED6: Labour cost

MED7: Economic inflation

MED8: Exchange rate

PC: Project cost

PC1: Capital construction cost

PC2: Associated capital cost

PC3: Client's other cost

FIgURE 1: The proposed research model. 
(iii) Hypothesis 3. Market and industry conditions can significantly impact project cost in New Zealand

(iv) Hypothesis 4. Regulatory regime has a significant effect on project cost in New Zealand

(v) Hypothesis 5. Macroeconomic dynamics can significantly affect project cost in New Zealand

The above hypotheses comprise a conceptual structural model and are also considered to be structural components of the SEM. As the factors that influence project cost are considered to be highly subjective, it is a complex matter to refine the right sort of measurement attributes for a true representation of the latent factors [46]. Based on a survey of the existing literature, a comprehensive list of attributes that clearly represent the five latent factors of the model was developed, as shown in Table 1. A thorough review of the perceived impacts and basic correlation analysis produced the following results: three attributes of project cost (PC1 to PC3), five attributes of project characteristics factor (PCF1 to PCF5), five attributes of key stakeholders' perspectives (KSP1 to KSP5), seven attributes of market and industry conditions (MIC1 to MIC7), five attributes of regulatory regime (RR1 to RR5), and eight attributes of macroeconomic dynamics (MED1 to MED8).

\section{Research Methodology}

According to Collis and Hussey [66], research methodology is defined as the overall approach used in a study, including all steps of the research process, from theoretical underpinnings to the data gathered and analysed. The research philosophy should be determined first, because research strategy and research methods decisions are based on the research philosophy [71]. This study attempts to capture the existing knowledge and information regarding influential factors of project cost and proposes a systematic approach and research model for the influential factors and project cost for New Zealand's construction industry. This study collected data about the influential factors using a questionnaire survey that was then quantitatively assessed. The data collection and analysis methods and the application of the existing knowledge represent an objectivism ontological position. In addition, a positivistic method was employed in this study, as the study depends on the experience and perspectives of key construction professionals.

4.1. Preparation of Questionnaire. In the initial stage of the study, a literature survey was performed to determine the influential factors of the project cost. Based on the literature survey, a questionnaire survey was constructed. To examine the effects of influential factors on project cost in New Zealand, the questionnaire survey collected the opinions of several key professionals in the construction industry of New Zealand. The key professionals rank the influencing factors using a 5 -point Likert scale ( $1=$ very weak, $2=$ weak, $3=$ medium, $4=$ strong, and $5=$ very strong). The main structure of the questionnaire consisted of five categories of influencing factors. Five hypotheses were then proposed according to the literature survey. Structural equation modelling was used to develop a conceptual model, based on the hypotheses. In the questionnaire design, the theory that at least three measurement variables reflect one latent variable was applied to develop a stable equation structural model [73].

Before executing the questionnaire survey, a pilot survey was conducted with a 12 -member reference group that explained the research intention and questions in order to ensure that the contents accurately translated the overall research model. Based on the feedback received, the questionnaire was refined. Ethics clearance for executing the questionnaire survey was obtained from the University Ethics Committee. The data were collected from six prominent associations/institutions in the construction industry in New Zealand. The target population of the questionnaire survey comprised developers, clients, consultants, contractors, and project managers. A total of 283 completed and reasonable questionnaire responses were collected from key construction industry professionals based on various locations of New Zealand. These responses provided the basis for further data analysis.

4.2. Respondents' Profiles. A total of seven hundred twentysix (726) questionnaires were distributed to clients and developers. Two hundred eighty-three (283) were completed and proved to be useful, representing a $39 \%$ response rate. A summary of the respondents' profiles is shown in Table 2. The response rate is considered to be successful since it exceeds the $37 \%$ threshold of the suggested response rate of a questionnaire survey of this kind [74]. Such a response rate was mainly due to the sample selection and the respondents' willingness to participate in the study. The valid data were then analysed using structural equation modelling in AMOS 23 software.

4.3. Structural Equation Modelling. Structural equation modelling (SEM) was used in this study for analysing complex relationships among the variables. SEM is an important technique for describing the possible interrelationships among the influential factors, to test the hypotheses, and to explore the relationships between the measurement indicators and corresponding latent factors [75]. The SEM approach has been widely used to explore causal relationships and test hypotheses in the education, management, and economics [76]. SEM includes multiple correlations and regressions, factor analysis, and path analysis. Compared with other multivariate analysis tools, SEM has several advantages: it involves multiple dependent variables and tests the interrelationships between independent variables; it includes latent variables in the model and measurement errors, and it develops a model that illustrates an entire set of relationships [73, 77].

SEM has been increasingly employed in constructionrelated research and studies because it can resolve construction-related problems [78]. For example, a SEM model was established for investigating the influencing factors for project-planning effectiveness, conducted by Islam and Faniran [79]; a developed SEM model was used to 
TABle 1: Categories of the influential factors.

\begin{tabular}{|c|c|c|}
\hline Construct & Measurement instrument & Source \\
\hline Project characteristics factor (PCF) & $\begin{array}{l}\text { Site accessibility } \\
\text { Project complexity } \\
\text { Procurement methods } \\
\text { Contract selection } \\
\text { Novel technology }\end{array}$ & {$[47-50]$} \\
\hline Key stakeholders' perspectives (KSP) & $\begin{array}{c}\text { Clients } \\
\text { Consultants } \\
\text { Contractors } \\
\text { Building officers } \\
\text { Suppliers }\end{array}$ & [51-56] \\
\hline Market and industry conditions (MIC) & $\begin{array}{c}\text { Resource market } \\
\text { Competition level } \\
\text { Boom and bust cycle } \\
\text { Relationship of supply and demand } \\
\text { Market properties } \\
\text { Investment tendency and confidence } \\
\text { House sell and rental prices }\end{array}$ & [57-61] \\
\hline Regulatory regime (RR) & $\begin{array}{c}\text { Building codes } \\
\text { Health and safety regulations } \\
\text { Political policy } \\
\text { Financial regulations } \\
\text { Construction contract act }\end{array}$ & [62-65] \\
\hline Macroeconomic dynamics (MED) & $\begin{array}{l}\text { Global economic trends } \\
\text { Global political conditions } \\
\text { Natural forces } \\
\text { Employment } \\
\text { Population } \\
\text { Labor cost } \\
\text { Economic inflation } \\
\text { Exchange rate }\end{array}$ & [66-72] \\
\hline Project cost $[68]$ & $\begin{array}{l}\text { Capital construction cost } \\
\text { Associated capital cost } \\
\text { Client's other costs }\end{array}$ & {$[17]$} \\
\hline
\end{tabular}

reveal the relationship between the project characteristics and project performance, performed by Cho et al. [77], while a SEM model was developed to establish the relationship between job cognition and cooperative behaviours, performed by Anvuur and Kumaraswamy [80]. Likewise, the SEM applied in this study aims to examine the effects of the influencing factors on New Zealand project cost.

Furthermore, SEM builds the relationship between the measurement variables and latent variables. Latent variables cannot be directly measured because of their abstract character. By contrast, measurement variables can be measured via a questionnaire survey. Several measurement variables can represent one latent variable $[79,81]$. An SEM model can be divided into two models: a measurement model and a structural model [82]. The measurement model is to examine the relationships between observed variables and latent constructs [83], and structural model is to investigate the relationships between latent constructs [84]. The measurement model can be expressed in the following equations:

$$
\begin{aligned}
& y_{i j}=\lambda_{i j} \eta_{j}+\omega_{i j}, \\
& x_{k l}=\delta_{k l} \xi_{l}+\varepsilon_{k l},
\end{aligned}
$$

where $y_{i j}$ indicates the $i$ observed indicator of the $j$ latent construct, $\lambda_{i j}$ is the correlation coefficient between $y_{i j}$ and $\eta_{j}$, $\eta_{j}$ represents the $j$ latent construct, $x_{k l}$ is the $k$ observed indicator of the $l$ latent construct, $\delta_{k l}$ is the correlation coefficient between $x_{k l}$ and $\xi_{l}, \xi_{l}$ indicates the $l$ latent construct, and $\omega_{i j}$ and $\varepsilon_{k l}$ are error terms. Project cost in this study is considered as endogenous latent construct measured by using equation (1) with measurement indicators PC1, PC2, and PC3, while the cost-influencing factors PCF are regarded as exogenous latent constructs measured by using equation (2) with corresponding measurement indicators.

The structural equation model can be expressed in the following equation

$$
\eta=B \eta+\Gamma \xi+\varepsilon
$$

where $\eta$ is the endogenous variable, $\xi$ is the exogenous variable, $B$ indicates the interactions between endogenous variables, $\Gamma$ is the coefficient matrix expressing the impacts of the exogenous variables on the endogenous variables, and $\varepsilon$ represents the error term.

As the conceptual model includes hypothetical relationships and multiple-path linkages (observed and latent variables and latent constructs), SEM is regarded as an appropriate method that can be used to achieve the research 
TABLE 2: Background information of the respondents.

\begin{tabular}{lc}
\hline & $\%$ \\
\hline Profession & \\
Developer & 21 \\
Asset manager & 18 \\
Engineers & 8 \\
Architecture & 11 \\
Quantity surveyor & 20 \\
Contractor & 12 \\
Project manager & 9 \\
Others & 1 \\
\hline Occupation & \\
Owners & 10 \\
Executives & 18 \\
Senior manager & 30 \\
Manager & 40 \\
Others & 2 \\
\hline Experience & \\
6-10 & 6 \\
10-15 & 17 \\
16-20 & 21 \\
21-25 & 27 \\
25-30 30 & 20 \\
Others & 8 \\
\hline Organisation & 1 \\
Property development & \\
Agency & 23 \\
Consultancy & 9 \\
Regulatory department & 48 \\
Project management & 2 \\
Others & 7 \\
\hline & \\
\hline
\end{tabular}

objectives. Therefore, a two-step analysis is often times used to develop a structural model [80, 81]. First, a confirmatory factor analysis (CFA) is performed to test the reliability and validity of the measurement variables and to provide a basis for the subsequent structural analysis. Then, the SEM was used to test the hypothesis or to explore the causal relationships between latent constructs. The overall fit of the model can be explored based on goodness-of-fit indices [85]. Only the model with satisfied goodness-of-fit indices can be accepted. Moreover, the paths with nonsignificant correlation coefficient should be removed to refine the structural model.

Many analysis software systems can be used to perform SEM analysis, such as AMOS, LISREL, and EQS [86]. Of these, AMOS 23 was used in this study. Analysis of a moment structures (AMOS) is statistical software, which is an added SPSS module and specially used for structural equation modelling [87]. In AMOS, models can be drawn graphically, and computation for SEM can be quickly conducted and displayed. The structural model comprises all five hypotheses that describe the relationships among the latent constructs, as shown in Figure 1.

\section{Data Analysis}

The data collected from the questionnaire survey were analysed using the SEM technique. Before performing the SEM analysis, the reliability test was conducted to evaluate the data quality. In the process of developing the structural equation model, it is required to specify the relationships among latent constructs and to describe the latent constructs represented by the corresponding measurement indicators. In the proposed research model, one endogenous latent variable (project cost) is predicted by five exogenous latent constructs (project characteristics factor, key stakeholders' perspectives, market and industry conditions, regulatory regime, and macroeconomic dynamics). A two-step method was adopted to develop the structural research model. Confirmatory factor analysis (CFA) is the first step and provides satisfactory goodness of fit. Following a satisfactory goodness of fit in the CFA stage, the next step was structural modelling between the latent variables to test the hypotheses proposed previously. Maximum likelihood estimation was employed in both the steps.

5.1. Confirmatory Factor Analysis. A reliability test is used to verify that the data are generally consistent with the research model. The reliability test for the research model was conducted by performing Cronbach's alpha test [88]. In Cronbach's alpha test, a cut-off value of 0.7 indicates an acceptable level of internal consistency. As seen from Table 3, the attributes measuring all six latent factors in the final research model show a high degree of reliability above the cut-off value.

Out of total 291 responses received, 283 were found effective and could therefore be used for further data analysis and model development. The reliability of the collected data was examined by using Cronbach's alpha [89], a method commonly used to check the internal consistency or reliability of items in a dataset. Alpha plays an important role in the evaluation of questionnaires and assessments [90]. Alpha, which was developed by Lee Cronbach in 1951, can be used to measure the internal consistency or reliability of a test or scale; the value ranges from 0 to 1 [91]. Internal consistency indicates the extent to which all the items in a test measure a same construct or concept and thus concerns the interrelatedness of the items in the test. Moreover, if a test has more than one construct or concept, it may make sense to calculate alpha for each one.

The hypothesised research model in Figure 1 was analysed by AMOS 23 software. The latent variable is reflected by at least three observed variables and their measurement errors. The observed variables are shown as rectangles, the latent variable is shown as ellipses, the measurement errors are shown as circles, and the arrows indicate the direction of effects. One coefficient between the latent variable and one of the observed variables should be established first (usually set as 1) in order to identify the measured item. Likewise, the starting value of 1 was given between PC and PC1, PCF and PCF2, KSP and KSP2, MIC and MIC2, RR and RR1, and MED and MED4. The standardised regression weights for each observed item are presented in Table 3.

According to [80], standardised regression weights greater than 0.5 indicate good convergent validity. As seen in Table 3, all measurement indicators were acceptable as qualified measurement indicators, except for novel technology, contract selection, suppliers, investment tendency 
TABle 3: Measurement model results and reliability test results.

\begin{tabular}{|c|c|c|c|}
\hline Variables & Abbr. & Standard coefficients & Cronbach's alpha \\
\hline $\begin{array}{l}\text { Project characteristics factor } \\
\text { Site accessibility } \\
\text { Project complexity } \\
\text { Supply chain } \\
\text { Contract selection* } \\
\text { Novel technology* }\end{array}$ & $\begin{array}{l}\text { PCF } \\
\text { PCF1 } \\
\text { PCF2 } \\
\text { PCF3 } \\
\text { PCF4 } \\
\text { PCF5 }\end{array}$ & $\begin{array}{c}0.876 \\
0.905 \\
0.889 \\
0.008^{*} \\
0.039^{*}\end{array}$ & 0.692 \\
\hline $\begin{array}{l}\text { Key stakeholders' perspectives } \\
\text { Clients } \\
\text { Consultants } \\
\text { Contractors } \\
\text { Building officers } \\
\text { Suppliers* } \\
\end{array}$ & $\begin{array}{c}\text { KSP } \\
\text { KSP1 } \\
\text { KSP2 } \\
\text { KSP3 } \\
\text { KSP4 } \\
\text { KSP5 } \\
\end{array}$ & $\begin{array}{c}0.898 \\
0.909 \\
0.876 \\
0.683 \\
0.074^{*} \\
\end{array}$ & 0.787 \\
\hline $\begin{array}{l}\text { Market and industry conditions } \\
\text { Resource markets } \\
\text { Competition level } \\
\text { Market properties } \\
\text { Boom and bust cycle } \\
\text { Relationship of supply and demand } \\
\text { Investment tendency and confidence* } \\
\text { House sell and rental prices* }\end{array}$ & $\begin{array}{l}\text { MIC } \\
\text { MIC1 } \\
\text { MIC2 } \\
\text { MIC3 } \\
\text { MIC4 } \\
\text { MIC5 } \\
\text { MIC6 } \\
\text { MIC7 }\end{array}$ & $\begin{array}{c}0.899 \\
0.908 \\
0.896 \\
0.897 \\
0.872 \\
0.153^{*} \\
0.142^{*}\end{array}$ & 0.745 \\
\hline $\begin{array}{l}\text { Regulatory regime } \\
\text { Building codes } \\
\text { Health and safety regulations } \\
\text { Political policy } \\
\text { Financial regulations } \\
\text { Construction contract act }\end{array}$ & $\begin{array}{l}\text { RR } \\
\text { RR1 } \\
\text { RR2 } \\
\text { RR3 } \\
\text { RR4 } \\
\text { RR5 }\end{array}$ & $\begin{array}{l}0.881 \\
0.883 \\
0.871 \\
0.851 \\
0.879\end{array}$ & 0.813 \\
\hline $\begin{array}{l}\text { Macroeconomic dynamics } \\
\text { Global economic trends } \\
\text { Global political stability } \\
\text { Natural forces } \\
\text { Employment } \\
\text { Population } \\
\text { Labor cost } \\
\text { Economic inflation* } \\
\text { Exchange rate* }\end{array}$ & $\begin{array}{l}\text { MED } \\
\text { MED1 } \\
\text { MED2 } \\
\text { MED3 } \\
\text { MED4 } \\
\text { MED5 } \\
\text { MED6 } \\
\text { MED7 } \\
\text { MED8 }\end{array}$ & $\begin{array}{r}0.778 \\
0.799 \\
0.816 \\
0.689 \\
0.693 \\
0.732 \\
0.070^{*} \\
0.111^{*}\end{array}$ & 0.745 \\
\hline $\begin{array}{l}\text { Project cost } \\
\text { Capital construction cost } \\
\text { Associated capital cost } \\
\text { Client's other cost }\end{array}$ & $\begin{array}{l}\text { PC } \\
\text { PC1 } \\
\text { PC2 } \\
\text { PC3 }\end{array}$ & $\begin{array}{l}0.772 \\
0.684 \\
0.715\end{array}$ & 0.756 \\
\hline
\end{tabular}

* The removed measurement indicators in the final model.

and confidence, housing sales and rental index, economic inflation, and exchange rate. After eliminating several measurement indicators, the final model was obtained, as shown in Figure 2. Among the deleted indicators, two attributes from project characteristics factor (PCF4 and PCF5), one attribute from key stakeholders' perspectives (KSP5), two attributes from market and industry conditions (MIC6 and MIC7), and two attributes from macroeconomic dynamics (MED7 and MED8) were eliminated. The elimination process is not discussed here in detail but a detailed discussion can be found in [92, 93].

5.2. Hypothesis Testing. In order to establish an acceptable final structural equation model, the initial structural model that is based on past theory and empirical findings may not be qualified without meeting the criterion of model fit [92].
Thus, goodness-of-fit (GOF) measurements were used in this study. According to Washington [82], measuring the GOF plays an important role in developing the structural equation model, and numerous GOF indices have been explored for this purpose. Generally, absolute fit, incremental fit, and parsimonious fit are used to judge the fitness of a model [94]. The fit between the data and the model was measured by different fit indices. As seen in Table 4, the final research model adequately satisfies the recommended level of GOF measurements. The chi-square/ $\mathrm{df}$ ratio of 1.786 and the GFI index value of 0.971 indicate an acceptable fit of the data. The root mean square error of approximation (RMSEA) value of 0.034 at $p<0.05$ indicates that the final model cannot be rejected at a high level of confidence. Furthermore, the values of all other essential indices, including normal fit index [101], comparative fit index (CFI), and normed fit index [101] were above their 


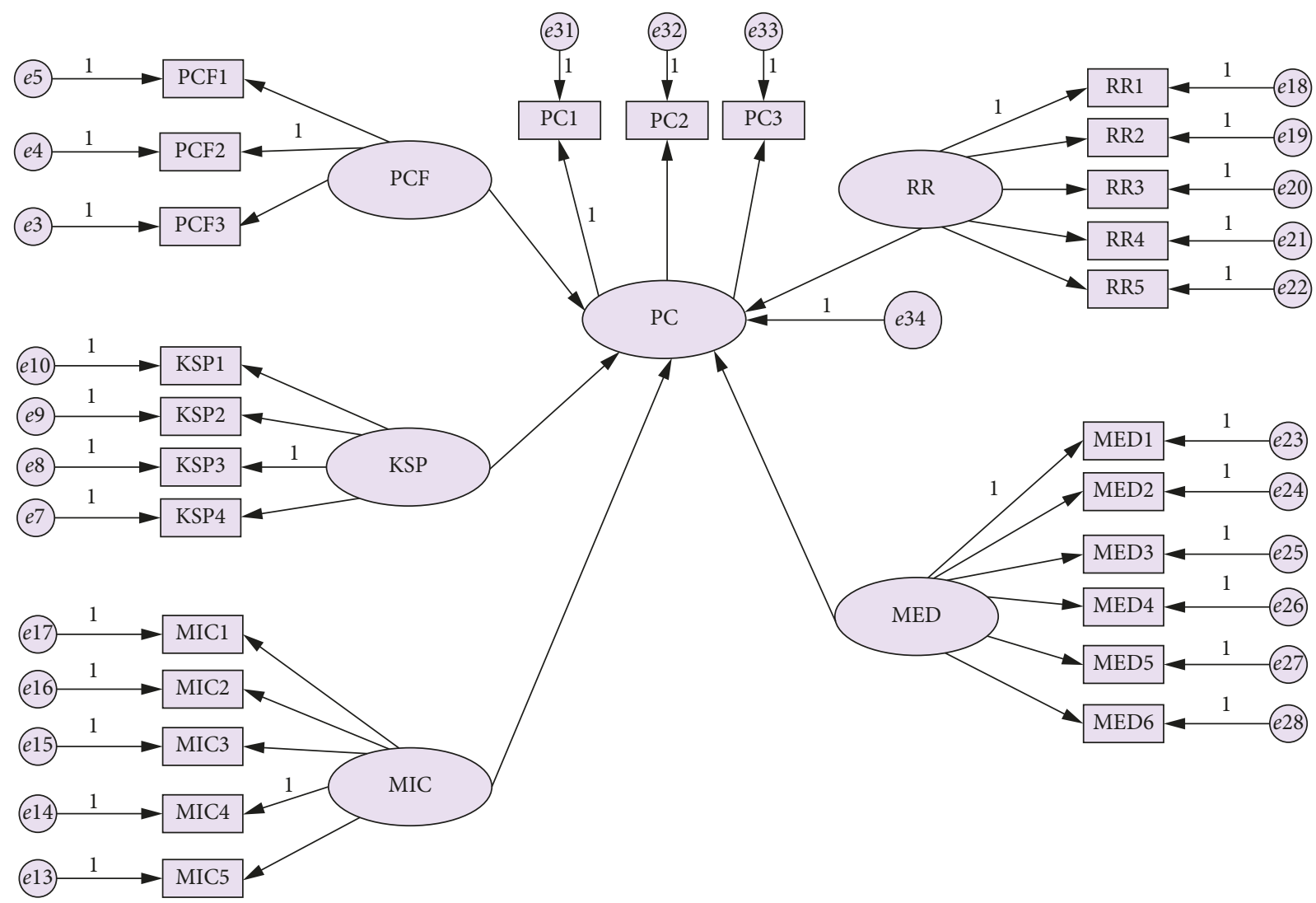

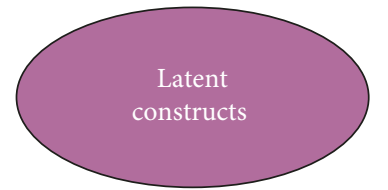

PCF: Project characteristics factor PCF1: Site accessibility PCF2: Project complexity PCF3: Supply chain KSP: Key stakeholders' perspectives KSP1: Clients

KSP2: Consultants KSP3: Contractors KSP4: Building officers MIC: Market and industry conditions MIC1: Resource markets

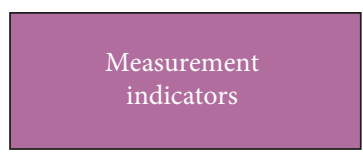

MIC2: Competition level MIC3: Market properties MIC4: Boom and bust cycle MIC5: Relationship of supply \& demand RR: Regulatory regime RR1: Building codes RR2: Health and safety regulations RR3: Political policy RR4: Financial regulations RR5: Construction contract act MED: Macro-economic dynamics

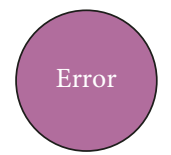

MED1: Global economic trends MED2: Global political stability MED3: Natural forces MED4: Employment MED5: Population MED6: Labour cost PC: Project cost PC1: Capital construction cost PC2: Associated capital cost PC3: Client's other cost

Figure 2: The final research model.

respective threshold values, which strongly support the satisfactory fit between the measurement model and the data [88]. Although the parsimony GOF index (PGFI) value of 0.895 shows a slight weakness in terms of the model fit, the value is above 0.7 and therefore cannot be rejected [102].

As shown in Table 5, all five hypotheses were supported by the SME analysis results (significance level of $p$ is less than $0.05)$. The path between market and industry conditions (MIC) to project cost [68] was statistically significant at $p=0$, which supports the hypothesis H3. Moreover, the path between regulatory regime (RR) to project cost [68] was statistically significant at $p=0.001$, which supports the hypothesis $\mathrm{H} 4$. The link between project characteristics factor (PCF) and project cost [68] was found to be statistically significant $(p=0.031)$, and thus, hypothesis $\mathrm{H} 1$ is supported. The path between key stakeholders' perspectives (KSP) and project cost [68] was statistically significant, with a $p$ value of 0.028 . The hypothetical path between macroeconomic dynamics (MED) and project cost [68] was marginally significant $(p=0.044)$. 
TABLE 4: Model fit indices of the proposed model.

\begin{tabular}{|c|c|c|c|c|c|c|}
\hline Measures & $\begin{array}{c}\text { Fit } \\
\text { index }\end{array}$ & Description & Range & $\begin{array}{l}\text { Recommend } \\
\text { level }\end{array}$ & $\begin{array}{c}\text { Model } \\
\text { index }\end{array}$ & Source \\
\hline \multirow{3}{*}{ Absolute fit measures } & $\mathrm{X}^{2} / \mathrm{df}$ & $\begin{array}{c}\text { Check whether the covariance structure of the } \\
\text { model is adequately the same as the covariance } \\
\text { matrix of the observed data }\end{array}$ & $>0$ & $1-2$ & 1.786 & [95] \\
\hline & GFI & $\begin{array}{l}\text { Check overall fit of the model; percent of the } \\
\text { covariance of the observed data can be explained } \\
\text { by the covariance of the model }\end{array}$ & $0-1$ & $>0.95$ & 0.971 & {$[96]$} \\
\hline & RMSEA & Check the mean value of the covariance residual & $>0$ & $<0.05$ & 0.034 & [97] \\
\hline \multirow[t]{2}{*}{ Incremental fit measures } & CFI & $\begin{array}{l}\text { Examine whether the model fits the observed data } \\
\text { better than the independent model that has no } \\
\text { relationships among variables }\end{array}$ & $0-1$ & $>0.9$ & 0.939 & [98] \\
\hline & NFI & $\begin{array}{l}\text { Explore the improvement of the overall fit of the } \\
\text { model to independent model }\end{array}$ & $0-1$ & $>0.8$ & 0.889 & [99] \\
\hline $\begin{array}{l}\text { Parsimonious fit } \\
\text { measures }\end{array}$ & PGFI & Examine the overall parsimony of the model & $0-1$ & $>0.7$ & 0.895 & {$[100]$} \\
\hline
\end{tabular}

TABLe 5: Hypothesis testing results.

\begin{tabular}{lccccc}
\hline Hypothesis & Causal relationship & Standardised regression coefficient & CR & $p$ value & Conclusion \\
\hline H1 & $\mathrm{PCF} \longrightarrow \mathrm{PC}$ & 0.650 & 2.632 & 0.031 & Support \\
$\mathrm{H} 2$ & $\mathrm{KSP} \longrightarrow \mathrm{PC}$ & 0.730 & 3.014 & 0.028 & Support \\
$\mathrm{H} 3$ & $\mathrm{MIC} \longrightarrow \mathrm{PC}$ & 0.817 & 4.516 & Support \\
$\mathrm{H} 4$ & $\mathrm{RR} \longrightarrow \mathrm{PC}$ & 0.810 & 3.718 & 0.001 & Support \\
$\mathrm{H} 5$ & $\mathrm{MED} \longrightarrow \mathrm{PC}$ & 0.610 & 2.038 & 0.044 & Support \\
\hline
\end{tabular}

$\mathrm{CR}=$ critical ratio; ${ }^{* * *}$ significant at 0.01 level.

\section{Findings and Discussion}

The final research model, after eliminating nonsignificant paths, is shown in Figure 2. The final research model suggests that market and industry conditions have the most significant effect (standardised coefficient $=0.817$ ) on project cost in New Zealand. The regulatory regime was found to be the second-most significant influencing factor (standardised coefficient $=0.81$ ) of project cost. The results also revealed that key stakeholders' perspectives can significantly influence (standardised coefficient $=0.73$ ) project cost. Among the five main factors, the project characteristics factor and macroeconomic dynamics (standardised coefficients of 0.65 and 0.61 , respectively) were also found to have significant effects on project cost in New Zealand. Our finding that the project characteristics factor had a significant effect on project cost is consistent with the widely accepted view across New Zealand's construction industry that the project characteristics factor is the main factor that influences project cost in New Zealand [25].

The results shown in Table 5 confirm the relationship between market and industry conditions and project cost, the relationship between the regulatory regime and project cost, and the relationship between key project perspectives and building development cost, which validate Hypotheses 2,3 , and 4 reasonably well. Moreover, a standardised coefficient of 0.65 between the project characteristics factor and a coefficient of 0.61 between the macroeconomic dynamics and the project cost support Hypotheses 1 and 5, respectively, as being valid. While macroeconomic dynamics is assumed to be one of the most significant influencing factors of project cost in New Zealand, the coefficient of 0.61 suggests that macroeconomic dynamics factor does have a significant effect on project cost. The result confirms previous research findings reported by MBIE [103], which asserted that macroeconomic dynamics is one of the most significant influencing factors of project cost. Moreover, based on the global economy integration findings of Jung and Han [45], macroeconomic dynamics may have significant indirect effects on overall economic activities, including construction activities.

This study assumed that key stakeholders' perspective is one of the key determinants of project cost in New Zealand, which is supported by the research findings of Scott-Young and Samson [104] who asserted that the expertise and experience of stakeholders are the most influential factors of project cost. This study proved the hypothesis that market and industry conditions can significantly affect project cost in New Zealand. This relationship supports earlier statements by Gliem and Gliem [105], who concluded that the majority of construction development is market driven. In doing so, it is not difficult to understand the explicit impact of market and industry conditions on project cost in New Zealand. The analysis results are consistent, to a certain extent, with recent studies $[40,41]$ in which the increasing demand for property likely triggers property values within an active market, and then, a rising market may be a driver for construction development. However, demand may fluctuate due to changes in the socioeconomic factor.

Furthermore, the results validate the hypothesis that the regulatory regime is an essential lawful contributor to project cost in New Zealand. Research has shown that a 
comprehensive understanding of the regulatory regimes of the construction industry and implementation of the project to suit the regimes contributes significantly to effective and efficient control of a project and thus has significant effects on project cost. Therefore, a project that experiences a lack of adequate understanding of the regulatory regime is less able to control costs. This finding corroborates previous research findings that showed that regulatory regimes in the construction industry are one of the main factors that influence project cost [42-44].

\section{Conclusions}

A framework is presented to describe the influencing factors of project cost in New Zealand. It provides a comprehensive view of influencing factors for projects cost in New Zealand, which provides insight into the dynamics of the project context. This framework comprises five categories of influencing factors: project characteristics, key stakeholders' perspectives, market and industry conditions, regulatory regime, and macroeconomic dynamics, which was used to develop a structural equation model to test the significance of the impact of the influencing factors on project cost in New Zealand. The study has demonstrated how factors of different categories can be combined in a model and how structural equation modelling can be employed to analyse underlying relationships between construction project cost and influencing factors.

The results support the assumption that the influencing factors can be grouped into five categories in New Zealand and confirm all five hypotheses. All five categories have significant effects on the movement of project cost in New Zealand. Market and industry conditions have the most significant effects on project cost, as this factor may be a major reason behind project efficiencies. These efficiencies have been found to have significant effects on project cost. Hence, clients should evaluate the market conditions, along with the statutory and regulatory regime of the project context before engaging. Moreover, the competence and collaboration of the professionals involved can improve project cost performance by facilitating information sharing. Hence, continuous professional development is necessary for industry professionals to advance their knowledge and understanding. In addition, this study also explored that health and safety regulations can impact project cost in a statistically significant manner. Hence, construction companies can develop safety programs based on the health and safety regulations.

Three important implications can be concluded from these results. First, this work demonstrates that classification of the influencing factors for project cost in New Zealand is meaningful. It is therefore necessary to classify the influencing factors before examining and evaluating their influencing effects on project cost, as different categories of influencing factors correlate differently with project cost. Second, the developed model improves the understanding of the movement of the project cost. For example, market and industry conditions have the most significant effect on project cost. Thus, a possible way to understand the movement of project cost is to understand the changes in market and industry conditions factor. The findings also provide a basis for further research that should account for the significant effects of the influencing factors on the movement of project cost in New Zealand. Given the frequency of project cost overruns in the construction industry and the uncertain and rapidly changing market conditions, a better understanding of risks can facilitate the decisionmaking process in this complex environment. The developed model can help industry professionals better understand the project context and the risks related to the project cost. It helps decision makers to identify the costrelated risks prior to the project construction and thus can help them avoid or alleviate those risks.

This study contributes in several ways. First, the study developed an overall, integrated structural model of project costs and validated the relationships between the observed variables and their corresponding latent constructs. Structural equation modelling (SEM) may become an innovative tool that can describe and explain the theoretical model better than traditional statistics and probabilities. Second, causal relationship between exogenous and endogenous latent constructs was identified. Finally, this study can improve project cost performance through the identification and evaluation of the cost-influencing factors.

However, some potential limitations exist in this study. The data are all derived from samples of key professionals in the construction industry in New Zealand. Although the conclusions are certainly valid for this sample set, their applicability outside of New Zealand is uncertain. In addition, although the sample size of 283 used in this study is appropriate for conducting structural equation modelling [106], more data can improve the model fit and enhance its validity. In further research, a more detailed study of the relationship between the five influencing factors and project cost with the consideration of the relationships among influencing factors in New Zealand will be examined and evaluated.

\section{Abbreviations}

SEM: Structural equation modelling

PCF: Project characteristics factor

PCF1: Site accessibility

PCF2: Project complexity

PCF3: Supply chain

PCF4: Contract selection

PCF5: Novel technology

KSP: Key stakeholders' perspectives

KSP1: Clients

KSP2: Consultants

KSP3: Contractors

KSP4: Building officers

KSP5: Suppliers

MIC: Market and industry conditions

MIC1: Resource markets

MIC2: Competition level

MIC3: Market properties

MIC4: Boom and bust cycle 
MIC5: Relationship of supply and demand

MIC6: Investment tendency and confidence

MIC7: House sell and rental prices

RR: Regulatory regime

RR1: Building codes

RR2: Health and safety regulations

RR3: Political policy

RR4: Financial regulations

RR5: Construction contract act

MED: Macroeconomic dynamics

MED1: Global economic trends

MED2: Global political stability

MED3: Natural forces

MED4: Employment

MED5: Population

MED6: Labor cost

MED7: Economic inflation

MED8: Exchange rate

PC: $\quad$ Project cost

PC1: Capital construction cost

PC2: Associated capital cost

PC3: Client's other costs.

\section{Data Availability}

The data used to support the findings of this study are available from the corresponding author upon request.

\section{Conflicts of Interest}

The authors declare that they have no conflicts of interest.

\section{References}

[1] The Treasury, The New Zealand Pacific Economy, The Treasury, Wellington, New Zealand, 2018.

[2] W. Lu, Y. Hua, and S. Zhang, "Logistic regression analysis for factors influencing cost performance of design-bid-build and design-build projects," Engineering, Construction and Architectural Management, vol. 24, no. 1, pp. 118-132, 2017.

[3] C. C. Cantarelli, B. Flyvbjerg, and S. L. Buhl, "Geographical variation in project cost performance: the Netherlands versus worldwide," Journal of Transport Geography, vol. 24, pp. 324-331, 2012.

[4] Y.-M. Cheng, "An exploration into cost-influencing factors on construction projects," International Journal of Project Management, vol. 32, no. 5, pp. 850-860, 2014.

[5] P. Sridarran, K. Keraminiyage, and L. Herszon, "Improving the cost estimates of complex projects in the project-based industries," Built Environment Project and Asset Management, vol. 7, no. 2, pp. 173-184, 2017.

[6] B. G. Hwang, H. Fang Tan, and S. Sathish, "Capital project performance measurement and benchmarking in Singapore," Engineering, Construction and Architectural Management, vol. 20, no. 2, pp. 143-159, 2013.

[7] M. S. B. A. A. El-Karim, O. A. M. El-Nawawy, and A. M. Abdel-Alim, "Identification and assessment of risk factors affecting construction projects," Housing and Building National Research Center Journal, vol. 18, no. 9, pp. 72-77, 2015.

[8] R. E. Meouche, M. Abunemeh, I. Hijaze, A. Mebarki, and I. Shahrour, "Developing optimal paths for evacuating risky construction sites," Journal of Construction Engineering and Management, vol. 144, no. 2, article 04017099, 2018.

[9] J. Yuan, A. Chan, W. Xiong, M. J. Skibniewski, and Q. Li, "Perception of residual value risk in public private partnership projects: critical review," Journal of Management in Engineering, vol. 31, no. 3, article 04014041, 2015.

[10] H. Doloi, A. Sawhney, K. C. Iyer, and S. Rentala, "Analysing factors affecting delays in Indian construction projects," International Journal of Project Management, vol. 30, no. 4, pp. 479-489, 2012.

[11] S. D. Zoysa and A. D. Russell, "Knowledge-based risk identification in infrastructure projects," Canadian Journal of Civil Engineering, vol. 30, no. 3, pp. 511-522, 2003.

[12] W. W. Chin, The Partial Least Squares Approach to Structural Equation Modelling, Lawrence Erlbaum Associates, Mahwah, NJ, USA, 1998.

[13] J. F. Hair, C. M. Ringle, and M. Sarstedt, "PLS-SEM: indeed a silver bullet," Journal of Marketing Theory and Practice, vol. 19, no. 2, pp. 139-152, 2011.

[14] A. Calvo-Mora, A. Leal, and J. L. Roldán, "Relationships between the EFQM model criteria: a study in Spanish universities," Total Quality Management \& Business Excellence, vol. 16, no. 6, pp. 741-770, 2005.

[15] A. Ashworth and S. Perera, Cost Studies of Buildings, Taylor \& Francis Group, London, UK, 6th edition, 2015.

[16] R. McCarthy, "Understanding project costs and building costs," The Bottom Line, vol. 17, no. 1, pp. 6-9, 2004.

[17] International Construction Measurement Standards (ICMS), Global Consistency in Presenting Construction Costs, International Construction Measurement Standards (ICMS), Westminster, UK, 2017.

[18] J. S. Shane, K. R. Molenaar, S. Anderson, and C. Schexnayder, "Construction project cost escalation factors," Journal of Management in Engineering, vol. 25, no. 4, pp. 221-229, 2009.

[19] C. Kaliba, M. Muya, and K. Mumba, "Cost escalation and schedule delays in road construction projects in Zambia," International Journal of Project Management, vol. 27, no. 5, pp. 522-531, 2009.

[20] H. S. Cha and K. Y. Shin, "Predicting project cost performance level by assessing risk factors of building construction in South Korea," Journal of Asian Architecture and Building Engineering, vol. 10, no. 2, pp. 437-444, 2011.

[21] H. Doloi, "Cost overruns and failure in project management: understanding the roles of key stakeholders in construction projects," Journal of Construction Engineering and Management, vol. 139, no. 3, pp. 267-279, 2013.

[22] I. A. Rahman, A. H. Memon, and A. T. A. Karim, "Significant factors causing cost overruns in large construction projects in Malaysia," Journal of Applied Sciences, vol. 13, no. 2, pp. 286-293, 2013.

[23] B. Sertyesilisik, A. Sourani, and A. Harris, "Identification of the critical success factors for maintenance contracts with target cost contracting," Journal of Modern Project Management, vol. 5, no. 2, 2017.

[24] L. I. Obi, M. Arif, and D. J. Kulonda, "Prioritizing cost management system considerations for Nigerian housing projects," Journal of Financial Management of Property and Construction, vol. 22, no. 2, pp. 135-153, 2017.

[25] D. J. Lowe, M. W. Emsley, and A. Harding, "Relationships between total construction cost and project strategic, site related and building definition variable," Journal of Financial Management of Property and Construction, vol. 11, no. 3, pp. 165-180, 2006. 
[26] T. Cooke-Davies, Aspects of Complexity: Managing Projects in a Complex World, Project Management Institute, Newtown Square, PA, USA, 2011.

[27] K. Remington, R. Zolin, and R Turner, "A model of project complexity: distinguishing dimensions of complexity from severity," in Proceedings of the 9th International Research Network of Project Management, Berlin, Germany, October 2009.

[28] S. L. Chan and M. Park, "Project cost estimation using principal component regression," Construction Management and Economics, vol. 23, no. 3, pp. 295-304, 2005.

[29] A. Warsame, Supplier Structure and Housing Construction Costs, Royal Institute of Technology, Stockholm, Swiden, 2006.

[30] C. Ivory and N. Alderman, "Can project management learn anything from studies of failure in complex systems?," Project Management Journal, vol. 36, no. 3, pp. 5-16, 2005.

[31] Construction Industry Development Board (CIDB), Construction Industry Master Plan 2006-2015, Construction Industry Development Board (CIDB), Kuching, Malaysia, 2006.

[32] S. A. Assaf and S. Al-Hejji, "Causes of delay in large construction projects," International Journal of Project Management, vol. 24, no. 4, pp. 349-357, 2006.

[33] A. M. Odeh and H. T. Battaineh, "Causes of construction delay: traditional contracts," International Journal of Project Management, vol. 20, no. 1, pp. 67-73, 2002.

[34] S. H. Park, "Whole life performance assessment: critical success factors," Journal of Construction Engineering and Management, vol. 135, no. 11, pp. 1146-1161, 2009.

[35] A. Al-Kharashi and R. M. Skitmore, "Causes of delays in Saudi Arabian public sector construction projects," Construction Management and Economics, vol. 27, no. 1, pp. 323, 2009.

[36] S. Kärnä, V. M. Sorvala, and J. M. Junnonen, "Classifying and clustering construction projects by customer satisfaction," Facilities, vol. 27, no. 9-10, pp. 387-398, 2009.

[37] F. Y. Y. Ling and C. L. K. Chong, "Design-and-build contractors' service quality in public projects in Singapore," Building and Environment, vol. 40, no. 6, pp. 815-823, 2005.

[38] R. Soetanto and D. G. Proverbs, "Modelling the satisfaction of contractors: the impact of client performance," Engineering Construction and Architectural Management, vol. 9, no. 5-6, pp. 453-465, 2002.

[39] L. Lehtiranta, S. Kärnä, J.-M. Junnonen, and P. Julin, “The role of multi-firm satisfaction in construction project success," Construction Management and Economics, vol. 30, no. 6, pp. 463-475, 2012.

[40] A. J. Shenhar, "One size does not fit all projects: exploring classical contingency domains," Management Science, vol. 47, no. 3, pp. 394-414, 2001.

[41] A. Shenhar and D. Dvir, Reinventing Project Management: The Diamond Approach to Successful Growth \& Innovation, Harvard Business School Press, Watertown, MA, USA, 2007.

[42] G. Levin and J. L. Ward, Program Management Complexity: A Competency Model, Taylor \& Francis Group, London, UK, 2011.

[43] H. Priemus, B. Flyvbjerg, and B. Wee, Decision-Making on Mega-Projects: Cost-Benefit Analysis, Planning and Innovation, Edward Elgar Publishing, Cheltenham, UK, 2008.

[44] A. Rolstadås, P. W. Hetland, G. F. Jergeas, and R. E. Westney, Risk Navigation Strategies for Major Capital Projects: Beyond the Risk of Predictability, Springer Science and Business Media, London, UK, 2011.
[45] W. Jung and S. H. Han, "Which risk management is most crucial for controlling project cost?," Journal of Management \& Engineering, vol. 33, no. 5, article 04017029, 2017.

[46] L. S. Aikin, J. A. Stein, and P. M. Bentler, "Structural equation analysis of clinical sub-population differences and comparative treatment outcomes: characterizing the daily lives of drug addicts," Journal of Consulting and Clinical Psychology, vol. 62, no. 3, pp. 488-499, 1994.

[47] N. Ahmad, F. Ismail, S. N. A. S. Alwi, and R. A. Rashid, "Important client attributes that influence project success: a focus on the briefing process," in Proceedings of the 2011 IEEE Symposium on Business, Engineering and Industrial Applications (ISBEIA2011), Langkawi, Malaysia, September 2011.

[48] M. O. Dada, "The influence of project team relationships on cost growth," Journal of Financial Management of Property and Construction, vol. 19, no. 1, pp. 76-94, 2014.

[49] A. Dahiru, "Appraising factors influencing construction engineering cost estimates," Journal of Engineering, Technology and Environmen, vol. 11, pp. 89-102, 2015.

[50] S. Olander and A. Landin, "Evaluation of stakeholder influence in the implementation of construction projects," International Journal of Project Management, vol. 23, no. 4, pp. 321-328, 2005.

[51] M. Ball, Markets and Institutions in Real Estate and Consturction, Blackwell, Oxford, UK, 2008.

[52] N. A. A. Bari, R. Yusuff, N. Ismail, A. Jaapar, and R. Ahmad, "Factors influencing the construction cost of industrialised building system (IBS) projects," Procedia-Social and Behavioral Sciences, vol. 35, pp. 689-696, 2012.

[53] F. M. Mckenzie and S. Rowley, "Housing market failure in a booming economy," Housing Studies, vol. 28, no. 3, pp. 373-388, 2013.

[54] T.-C. Toh, C. Ting, K.-N. Ali, G.-U. Aliagha, and O. Munir, "Critical cost factors of building construction projects in Malaysia," in Proceedings of the International Conference on Asia Pacific Business Innovation and Technology Management, Kuala Lumpur, Malaysia, January 2012.

[55] X.-H. Jin and F. Y. Y. Ling, "Key relationship based determinants of project performance in China," Journal of Building and Environment, vol. 41, no. 7, pp. 915-925, 2006.

[56] H. Xiao and D. Proverbs, "Factors influencing contractor performance: an international investigation," Engineering, Construction and Architectural Management, vol. 10, no. 5, pp. 322-332, 2003.

[57] P. Garg and A. Garg, "Factors influencing ERP implementation in retail sector: an empirical study from India," Journal of Enterprise Information Management, vol. 27, no. 4, pp. 424-448, 2014.

[58] V. B. Gargeya and C. Brady, "Success and failure factors of adopting SAP in ERP system implementation," Business Process Management Journal, vol. 11, no. 5, pp. 501-516, 2005.

[59] B.-G. Hwang and J. S. Tan, "Green building project management: obstacles and solutions for sustainable development," Sustainable Development, vol. 20, no. 5, pp. 335-349, 2012.

[60] Y.-T. Lai, W.-C. Wang, and H.-H. Wang, "AHP- and simulation-based budget determination procedure for public building construction projects," Automation in Construction, vol. 17, no. 5, pp. 623-632, 2008.

[61] B. A. Muhammad, I. Abdulateef, and B. D. Ladi, "Assessment of cost impact in health and safety on construction projects," 
American Journal of Engineering Research, vol. 4, no. 3, pp. 25-30, 2015.

[62] A. Ansar, B. Flyvbjerg, A. Budzier, and D. Lunn, "Does infrastructure investment lead to economic growth or economic fragility? Evidence from China," Oxford Review of Economic Policy, vol. 32, no. 3, pp. 360-390, 2016.

[63] B. Bahadir and O. Mykhaylova, "Housing market dynamics with delays in the construction sector," Journal of Housing Economics, vol. 26, pp. 94-108, 2014.

[64] Y. Chang-Richards, S. Wilkinson, R. Potangaroa, and E. Seville, "Resource challenges for housing reconstruction: a longitudinal study of the Australian bushfires," Disaster Prevention and Management: An International Journal, vol. 22, no. 2, pp. 172-181, 2013.

[65] J. Rodriguez, Construction Contracting: All about Cost-Plus Contract, The Balance, London, UK, 2017.

[66] J. Collis and R. Hussey, Business Research: A Practical Guide for Undergraduate and Postgraduate Students, Palgrave Macmillan, Basingstoke, UK, 2009.

[67] N. J. Lavingia, "Improve profitability through effective project management and TCM," Cost Engineering, vol. 45, no. 11, pp. 22-24, 2003.

[68] J. Lipczynski, J. O. S. Wilson, and J. A. Goddard, Industrial Organization: Competition, Strategy, Policy, Prentice Hall/ Financial Times, Upper Saddle River, NJ, USA, 2nd edition, 2005.

[69] A. Panibratov, "Internationalization process of Russian construction industry: inward investments perspective," Journal of East European Management Studies, vol. 14, no. 2, pp. 210-228, 2009.

[70] D. B. Rosenbaum, "Questions hamper deals," Engineering News Record, vol. 24, no. 11, 1997.

[71] M. Saunders, P. Lewis, and A. Thornhill, Research Methods for Business Students, Pearson Education, London, UK, 5th edition, 2009.

[72] M. Trabelsi and M. Cherif, "Capital account liberalization and financial deepening: does the private sector matter?," The Quarterly Review of Economics and Finance, vol. 64, pp. 141-151, 2017.

[73] R. B. Keline, Principles and Practice of Structural Equation Modeling, The Guilford Press Inc., New York, USA, 2005.

[74] J. P. Stevens, Applied Multivariate Statistics for the Social Sciences, Lawrence Erlbaum Associates, Mahwah, NJ, USA, 2002.

[75] J. F. Hair, Multivariate Data Analysis, Pearson Education International, Upper saddle River, NJ, USA, 2010.

[76] B. Xiong, M. Skitmore, and B. Xia, "A critical review of structural equation modeling applications in construction research," Automation in Construction, vol. 49, pp. 59-70, 2015.

[77] K. Cho, T. Hong, and C. Hyun, "Effect of project characteristics on project performance in construction projects based on structural equation model," Expert Systems with Applications, vol. 36, no. 7, pp. 10461-10470, 2009.

[78] A. E. Oke, D. R. Ogunsami, and S. Ogunlana, "Establishing a common ground for the use of structural equation modelling for construction related research studies," Construction Economics and Building, vol. 12, no. 3, pp. 89-94, 2012.

[79] M. D. M. Islam and O. O. Faniran, "Structural equation model of project planning effectiveness," Construction Management and Economics, vol. 23, no. 2, pp. 215-223, 2005.

[80] A. M. Anvuur and M. M. Kumaraswamy, "Measurement and antecedents of cooperation in construction," Journal of
Construction Engineering and Management, vol. 138, no. 7, pp. 797-810, 2012.

[81] B. M. Byrne, Structural Equation Modeling with AMOS: Basic Concepts, Applications, and Programming, Routledge, Abingdon, New York, USA, 2010.

[82] S. Washington, Statistical and Econometric Methods for Transportation Data Analysis, Chapman and Hall/CRC, Boca Raton, FL, USA, 2011.

[83] S. M. Qureshi and C. Kang, "Analysing the organizational factors of project complexity using structural equation modelling," International Journal of Project Management, vol. 33, no. 1, pp. 165-176, 2015.

[84] M. Suprapto, H. L. M. Bakker, and H. G. Mooi, "Relational factors in owner-contractor collaboration: the mediating role of team working," International Journal of Project Management, vol. 33, no. 6, pp. 1347-1363, 2015.

[85] R. Ho, Handbook of Univariate and Multivariate Data Analysis with IBM SPSS, Taylor \& Francis, Boca Raton, FL, USA, 2nd edition, 2014.

[86] J.-B. Yang and S.-F. Ou, "Using structural equation modeling to analyze relationships among key causes of delay in construction," Canadian Journal of Civil Engineering, vol. 35, no. 4, pp. 321-332, 2008.

[87] The Division of Statistics, Structural Equation Modeling Using AMOS: An Introduction, The University of Texas, Austin, TX, USA, 2012.

[88] X. H. Jin, H. Doloi, and S. Y. Gao, "Relationship-based determinants of building project performance in China," Construction Management and Economics, vol. 25, no. 3, pp. 297-304, 2007.

[89] N. Schmitt, "Uses and abuses of coefficient alpha," Psychological Assessment, vol. 8, no. 4, pp. 350-353, 1996.

[90] M. Tavakol and R. Dennick, "Making sense of Cronbach's alpha," International Journal of Medical Education, vol. 2, pp. 53-55, 2011.

[91] L. J. Cronbach, "Coefficient alpha and the internal structure of tests," Psychometrika, vol. 16, no. 3, pp. 297-334, 1951.

[92] K. Molenaar, S. Washington, and J. Diekmann, "Structural equation model of construction contract dispute potential," Journal of Construction Engineering \& Management, vol. 126, no. 4, pp. 268-277, 2000.

[93] P. S. P. Wong and S. O. Cheung, "Structural equation model of trust and partnering success," Journal of Management in Engineering, vol. 21, no. 2, pp. 70-80, 2005.

[94] T. F. Ong and G. Musa, "Examining the influences of experience, personality and attitude on SCUBA divers' underwater behaviour: a structural equation model," Tourism Management, vol. 33, no. 6, pp. 1521-1534, 2012.

[95] R. B. Kline, Principles and Practice of Structural Equation Modelling: Methodology in the Social Sciences, Guilford Press, New York, NY, USA, 2005.

[96] L. t. Hu and P. M. Bentler, "Cutoff criteria for fit indexes in covariance structure analysis: conventional criteria versus new alternatives," Structural Equation Modeling: A Multidisciplinary Journal, vol. 6, no. 1, pp. 1-55, 1999.

[97] D. A. Kenny, B. Kaniskan, and D. B. McCoach, "The performance of RMSEA in models with small degrees of freedom," Sociological Methods \& Research, vol. 44, no. 3, pp. 486-507, 2015.

[98] P. M. Bentler, "Comparative fit indexes in structural models," Psychological Bulletin, vol. 107, no. 2, pp. 238-246, 1990. 
[99] R. E. Schumacker and R. G. Lomax, A Beginner's Guide to Structural Equation Modeling, Lawrence Erlbaum Associates, Mahwah, NJ, USA, 2nd edition, 2004.

[100] E. H. O'Boyle and L. J. Williams, "Decomposing model fit: measurement vs. theory in organizational research using latent variables," Journal of Applied Psychology, vol. 96, no. 1, pp. 1-12, 2011.

[101] Y. Rosenfield, "Root-cause analysis of construction-cost overruns," Journal of Construction Engineering and Management, vol. 140, no. 1, article 04013039, 2014.

[102] G. D. Wood and R. C. T. Ellis, "Main contractor experiences of partnering relationships on UK construction projects," Construction Management and Economics, vol. 23, no. 3, pp. 317-325, 2005.

[103] Ministry of Business, Innovation \& Employment (MBIE), Housing Pressures in Christchurch, Ministry of Business, Innovation \& Employment (MBIE), Wellington, New Zealand, 2013.

[104] C. Scott-Young and D. Samson, "Project success and project team management: evidence from capital projects in the process industries," Journal of Operations Management, vol. 26, no. 6, pp. 749-766, 2008.

[105] T. Havard, Financial Feasibility Studies for Property Development Theory and Practice, Taylor \& Francis Group, London, UK, 2014.

[106] J. A. Gliem and R. R. Gliem, "Calculating, interpreting, and reporting Cronbach's alpha reliability coefficient for Likerttype scales," in Proceedings of the Midwest Research-toPractice Conference in Adult, Continuing and Community Education, St. Louis, MO, USA, October 1989. 


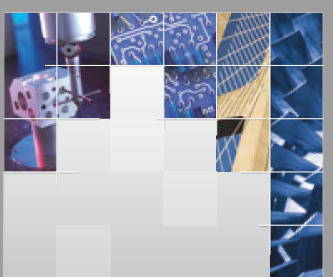

\section{Enfincering}
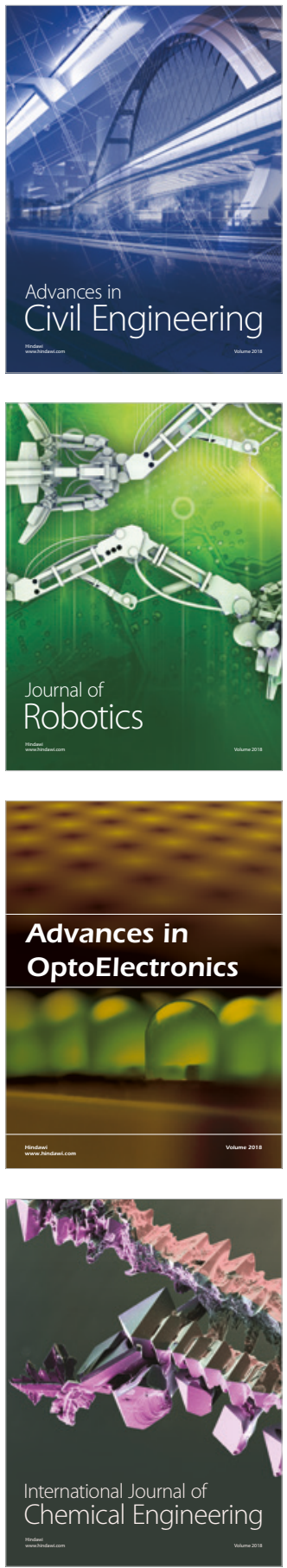

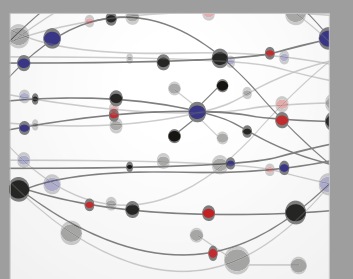

\section{Rotating \\ Machinery}

The Scientific World Journal

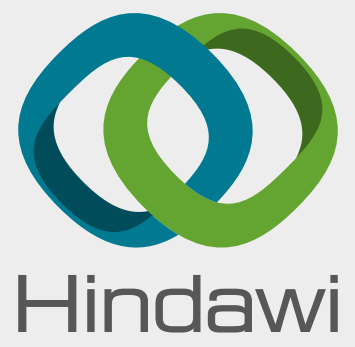

Submit your manuscripts at

www.hindawi.com
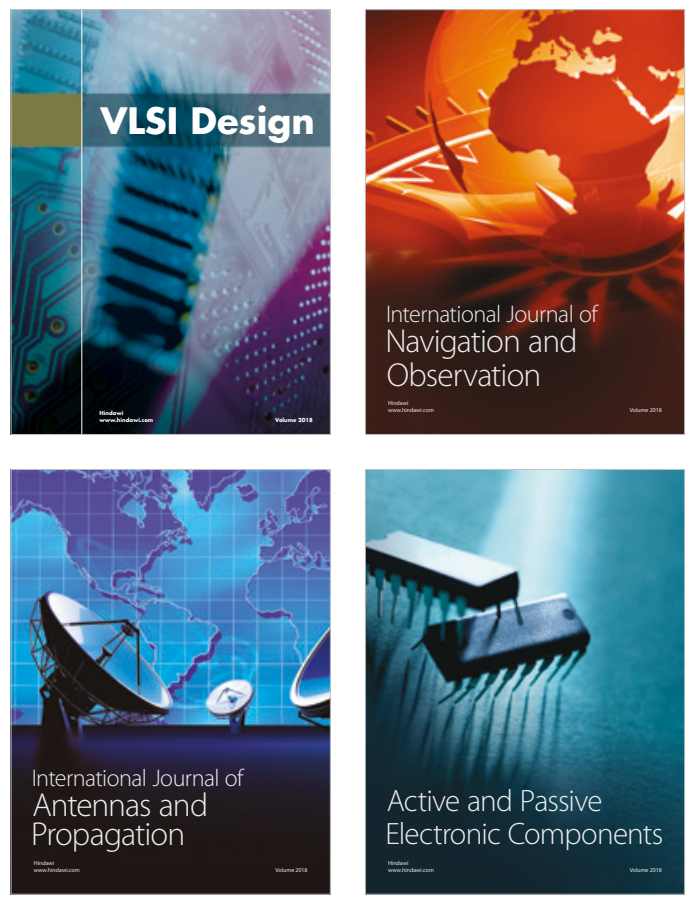
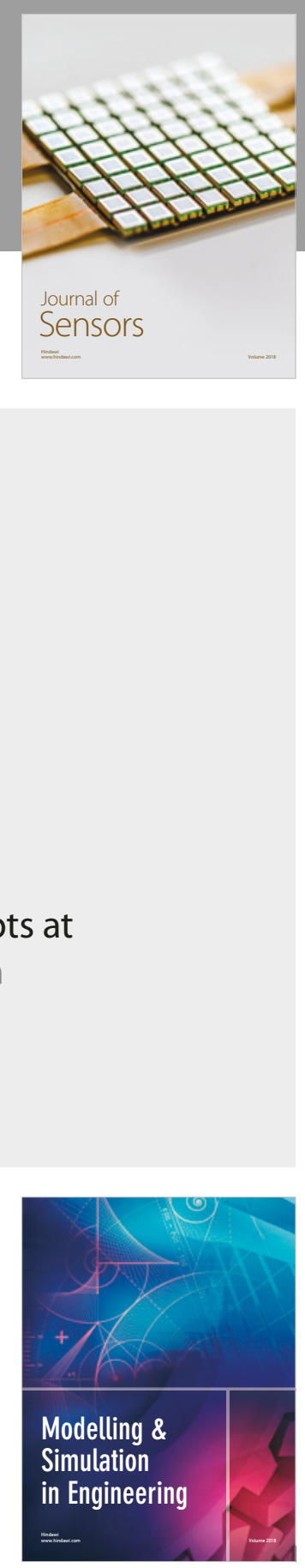

\section{Advances \\ Multimedia}
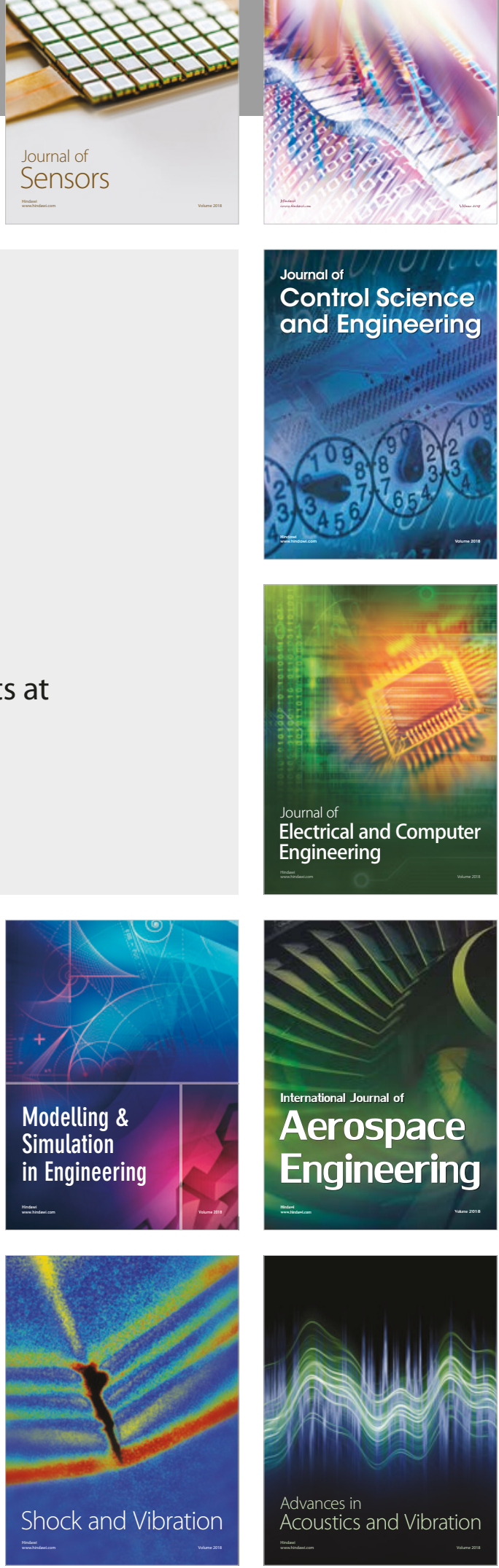